\title{
Gravitációs beömlõrendszerek áramlási tulajdonságainak összehasonlítása számítógépes szimuláció segítségével
}

\author{
Fazekas Ferenc
}

Abstract: In the following essay, different types of gravitally gutter systems has been studied. Computer aid numerical analysis has been used to compare four different geometry in case of laminar and turbulent inrun flow. The aim of the study was to prevent the forming of oxide inclusions during casting, and to increase the outrun speed of the liquid metal from the gutter.

\section{Bevezetés}

Mind gravitációs, mind nyomásos öntészet esetében, a beömlõrendszerrel szemben támasztott elsõdleges követelmény, hogy a formaüreget képes legyen megtölteni fémmel, mielõtt a hûlésnek leginkább kitett öntvényrészen a dermedés megkezdõdne. Ezen fõ cél mellett gyakran háttérbe szorulnak más lényeges szempontok, mint például az áramlási viszonyok optimalizálása a beömlõben. Márpedig az erõsen turbulens áramlás, vagy a káros hullámzás kialakulása egyrészt növeli az oxidzárványok kialakulásának esélyét, másrészt csökkenti az áramlás sebességét. Amennyiben csökken az áramlás sebessege, abban az esetben nagyobb keresztmetszeû, azaz nagyobb tömegû beömlõrendszert kell alkalmazni azonos formatöltési idõ eléréséhez. A kész öntvényrõl a beömlõrendszer eltávolításra kerül, és visszajáró hulladékként hasznosítják újra. Egy kedvezõbb áramlási tulajdonságokkal rendelkezõ, kisebb tömegû beömlõ, tehát növeli az öntvénykihozatalt, ezáltal költségmegtakaritás erhetõ el.

Különbözõ számitásokat végeztem Japánban, a Nagaoka University of Technology -n, egy ilyen, kedvezõbb áramlási tulajdonságokkal rendelkezõ beömlõrendszer tervezése céljából.

\section{A kísérlet leirása}

A végeselemes áramlási szimulációkat SUN Sparc Station 20 workstation számitógépen, Soldia EX 4.0 és Soldia FLOW 2.0 softwarek segitségével végeztem. Az öntés során a fém hõmérséklete állandó volt.A kísérlet adatai: a fém sûrûsége 7.0 gramm per köbcentiméter, hõmérséklete 1400 
celsius fok, dinamikai viszkozitása 0.001 négyzetcentiméter per szekundum, beömlési sebesség 10 centiméter per szekundum. Ezek az adatok szürketöretû öntöttvasnak felelnek meg. Minden geometria estén azonos, 4250 köbcentiméter térfogatú formaüreget alkalmaztam. A metallosztatikai nyomómagasság, és az álló középtengelyének a megvágástól mért távolsága szintén azonos volt minden kalkuláció esetén. A megvágások keresztmetszete 1000 négyzetmiliméter.

Négy különbözõ geometrián végeztem számításokat. Az alap (hagyományos) beömlõrendszernél a megvágás : elosztócsatorna, illetve megvágás : álló keresztmetszetarányok $1: 1.4$ illetve $1: 1.6$ voltak. A geometria elölnézetben az 1 . ábrán látható. A további három geometria esetén a keresztmetszetek csökkennek az álló tetejétõl a megvágásig. A szabadon esõ fémsugár keresztmetszete ugyanis folyamatosan csökken, ahogy sebessége nõ. Mivel a software adottságai nem engedték meg, hogy folyamatosan csökkenõ keresztmetszetekkel végezzek számításokat, így néhány metallosztatikai nyomómagassághoz megállapitottam a fémsugár keresztmetszetét $(80,110$, 140, 180 miliméternél), és ennek megfelelõen csökkentettem az alló keresztmetszetét is. A 2. ábrán kör keresztmetszet esetére kialakitott geometria látható. Ugyanazon területû, de szabályos háromszög illetve négyzet keresztmetszetekre is elvégeztem a számításokat.

Hosszabb formatoltési idõ esetén a fém a gravitációs mezõ hatására megpördülhet az állóban. A gravitáció ezen hatását a software nem vette figyelembe, ezért a 3 . ábrán látható geometriát alkalmazva a fémet tangenciális megvágás mentén juttattam be az öntõtölcsérbe.

\section{Eredmények nem megpördített fém esetére}

Hagyományos geometria esetén az öntés kezdetén a fémsugár keresztmetszete csökkent. Ezt a csökkenést a formaüreg nem követi, így a fém elválik a forma falától. Az álló alján, amikor a fém eléri az elosztócsatornát, feltorlódik és így a formafal és a fémsugár között levegõbezáródás keletkezik. Amint a fém az elosztócsatornában eléri a megvágást, a formaüreg keresztmetszete hirtelen ismét csökken, ezért a fém megint feltorlódik. Ennek hatására az elosztócsatornában kialakul egy visszafelé haladó olvadékhullám.

A további három beömlõrendszer esetében megfigyelhetõ, hogy a fém nem válik el a formafaltól, mivel annak keresztmetszete követi a folyadéksugár keresztmetszetcsökkenését. Mivel a beömlõben nincsenek hirtelen keresztmetszetcsökkenések, ezért nem alakul ki sem fémfeltorlódás, sem visszafelé haladó hullám. A legsimább lefutású formatöltés kör keresztmetszet esetén érhetõ el. Mindhárom beömlõrendszernél megfigyelhetõ, hogy amikor a fémsugár a könyökhöz ér, a külsõ falhoz csapódik, mozgásiránya megváltozik es egyben sebessége is lecsökken. A belsõ iven a sugár elválik a formafaltól, de levegõbezáródás nem keletkezik, mert nincs visszafelé mutató áramlás. A sebeség a belsõ íven a legnagyobb. A legnagyobb kifolyási sebesség kör keresztmetszet esetén erhetõ el. 

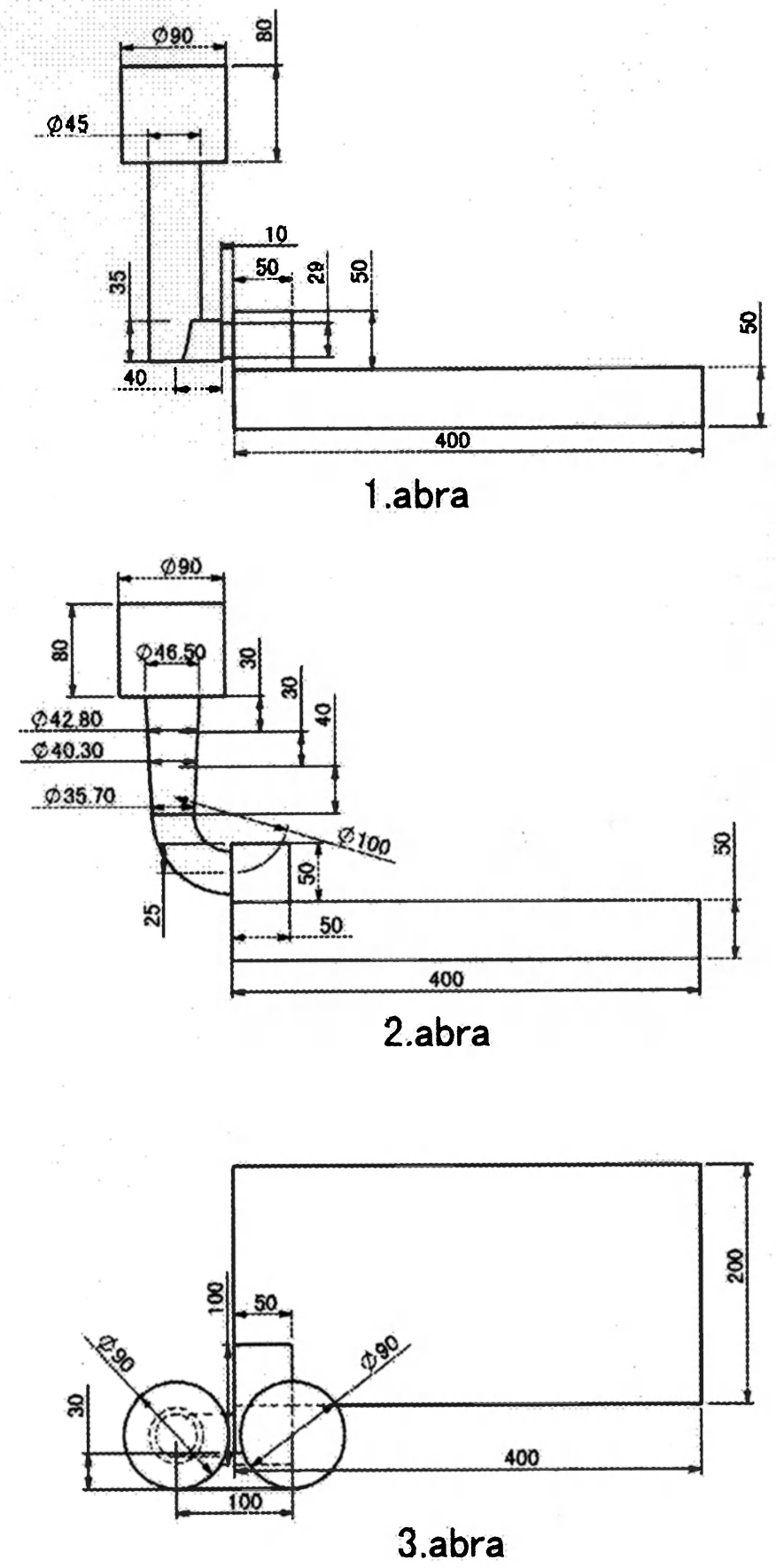


\section{Eredmények megpördített fém esetére}

Minden geometria esetén megfigyelhetõ, hogy a fém körben áramlik az álló részen, ezért egy nagy térfogatú levegõtölcsér alakul ki az álló középvonalában. Az áramlás teljes keresztmetszete igy lényegesen lecsökken. Ennek következtében a formatöltési idõ nagymértékben megnõ. Háromszög és négyzet keresztmetszet esetén a forgási sebesség jelentõsen csökken a sarkos forma miatt, ennek ellenére a formatöltési idõ nem csökken. Ennek oka, hogy az álló tetején a beömlõtölcsérben a fém forgását nem csökkenti semmi, így a fém utánpótlása azonos minden esetben. A szögletes keresztmetszetek estén azonban a fém több sugárra, esetenként cseppekre bomlik, ami káros hatású, mivel elõsegíti az oxidzárványok kialakulását. A legnagyobb áramlási sebesség kör keresztmetszet esetén figyelhetõ meg.

A számítások tehát azt mutatják, hogy mind megpördített, mind megpördítetlen fém esetén a 2 - 3 ábrán látható beömlõrendszer adja a legsimább lefutású, leggyorsabb formatöltést.

\section{Irodalom}

1, Introduction to Computer Simulation Nancy Roberts, David F. Andersen, Ralph M. Dean Addison - Wesley Publishing Company 1983 Sydney.

2, Fluid Mechanics

McGraw - Hill Kogakusha LTD

Theodore Allen Jr., Richard L. Dusworth

1972 Tokyo.

3, Metals Handbook 8 th edition Vol. 5 Forging and Casting

American Society for Metals

1970 Metals Park, Ohio.

Fazekas Ferenc, doktorandusz, Miskolci Egyetem, Öntészeti Tanszék, H3515, Miskolc Egyetemváros 